\section{Surfing the spectrum - what is on the horizon?}

\author{
P. Lancaster, ${ }^{* 1}$ F. Carmichael, ${ }^{1}$ J. Britton, ${ }^{2}$ H. Craddock, ${ }_{1}^{3}$ D. Brettle ${ }^{2}$ \\ and V. Clerehugh'
}

VERIFIABLE CPD PAPER

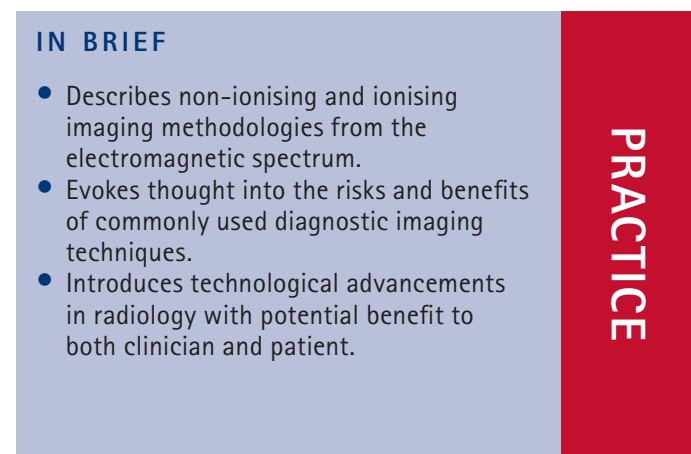

Diagnostic imaging techniques have evolved with technological advancements - but how far? The objective of this article was to explore the electromagnetic spectrum to find imaging techniques which may deliver diagnostic information of equal, or improved, standing to conventional radiographs and to explore any developments within radiography which may yield improved diagnostic data. A comprehensive literature search was performed using Medline, Web of Knowledge, Science Direct and PubMed Databases. Boolean Operators were used and key-terms included (not exclusively): terahertz, $X$-ray, ultraviolet, visible, infra-red, magnetic resonance, dental, diagnostic, caries and periodontal. Radiographic techniques are primarily used for diagnostic imaging in dentistry, and continued developments in X-ray imaging include: phase contrast, darkfield and spectral imaging. Other modalities have potential application, for example, terahertz, laser doppler and optical techniques, but require further development. In particular, infra-red imaging has regenerated interest with caries detection in vitro, due to improved quality and accessibility of cameras. Non-ionising imaging techniques, for example, infra-red, are becoming more commensurate with traditional radiographic techniques for caries detection. Nevertheless, $\mathrm{X}$-rays continue to be the leading diagnostic image for dentists, with improved diagnostic potential for lower radiation dose becoming a reality.

\section{INTRODUCTION}

Radiographic imaging using X-rays has been the primary diagnostic imaging technology used within the dental profession since its discovery in 1895 . However, it is an ionising radiation with some detrimental effects to our health ${ }^{1}$ and has limitations, for example, superimposition of anatomical structures and poor contrast of soft-tissue. Radiographic imaging is, to a large extent, technology limited and has advanced rapidly, particularly in recent years with the development of digital imaging. $\mathrm{X}$-rays are also part of the electromagnetic spectrum. The aim of this literature review was to revisit diagnostic imaging considering not just technological advancements, but also the entire electromagnetic spectrum (Fig. 1). The objective is

'Leeds Dental Institute, Worsley Building, Clarendon Way, Leeds, LS2 9LU; ${ }^{2}$ Old Medical School, Leeds General Infirmary, Leeds, LS1 3EX; ${ }^{3}$ University of Aberdeen Dental School, Cornhill Road, Aberdeen, AB25 2ZR *Correspondence to: Miss Paula Lancaster Email: p.e.lancaster@leeds.ac.uk

\section{Refereed Paper}

Accepted 3 June 2013

DOI: 10.1038/sj.bdj.2013.994

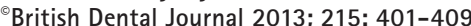

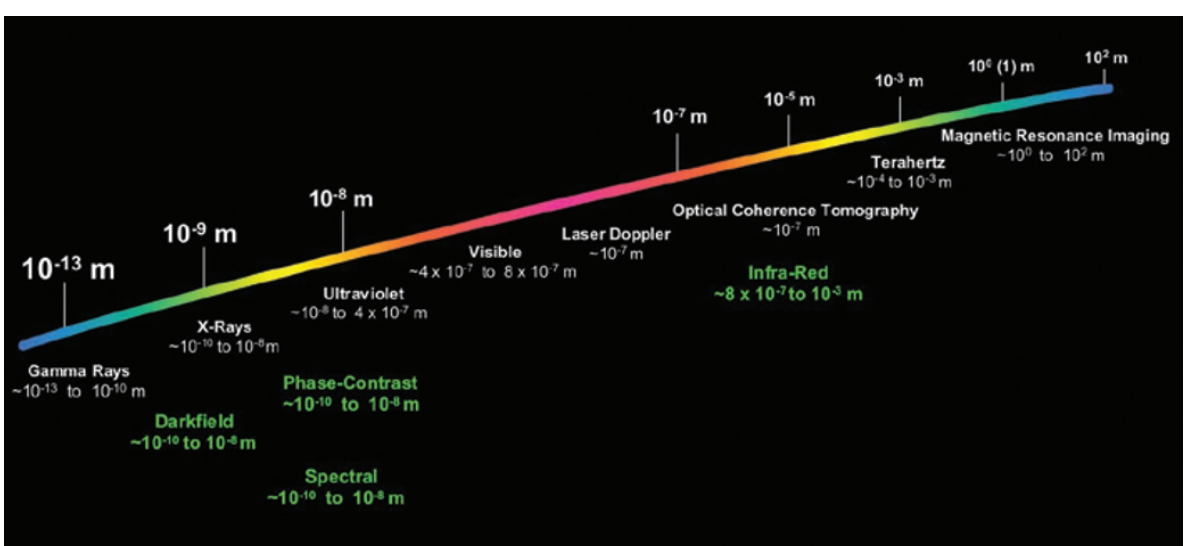

Fig. 1 The electromagnetic spectrum

to identify alternative imaging techniques, $\mathrm{X}$-ray or otherwise, which may deliver complementary diagnosis, lower dose or better diagnostic efficacy than current techniques. Some of the options available are discussed below.

\section{METHOD}

A comprehensive review of four databases, that is, Medline, PubMed, Science Direct and Web of Knowledge, was undertaken. General and restorative dental terminologies were combined with the imaging options from the electromagnetic spectrum and Boolean Operators were applied. Exclusion criteria included articles of language other than English.

\section{RESULTS}

\section{MAGNETIC RESONANCE IMAGING (WAVELENGTH $\sim 10^{\circ} \mathrm{TO} 10^{2} \mathrm{M}$ )}

This uses a static 0.1-8 Tesla magnetic field and a radio pulse, both of which are non-ionising radiation, to produce $2 \mathrm{D}$ or 3D digital images of tissues, for example, tumour staging, TMJ and intra-cranial lesions. The ability to see through bone 
avoids superimposition of structures and calcified and non-calcified tissues are illustrated (Fig. 2). ${ }^{2}$ Functional images which provide physiological information are possible with real time sequences and good resolution $(50 \mu \mathrm{m} \times 50 \mu \mathrm{m} \times 350 \mu \mathrm{m})$. However, specialist equipment of considerable size and expense is required and a contrast medium is often used for soft tissue, for example, gadolinium, which requires intra-venous administration. ${ }^{3}$ Gadolinium is contra-indicated in patients with renal impairment. Capture of the image is lengthy and the machines are very noisy and claustrophobic. The magnetic field is a problem for people with metallic implants of any description and dental restorations can distort the image.

\section{TERAHERTZ IMAGING \\ (WAVELENGTH OF $\sim 10^{-4}$ TO $10^{-3} \mathrm{M}$ )}

Also known as sub-millimetre or T-waves. Production of these waves is possible by exposure of zinc-telluride crystals to pulses of visible or infra-red light and detection is now feasible with advancements in photoconductive detectors. ${ }^{4}$ Terahertz pulses are strongly absorbed by water, and tissue penetration appears to be limited to the micron level. ${ }^{5}$ Image production is from the reflected wave (Fig. 3$)^{6}$ and in mineralised tissue it is proving difficult to focus the reflected beam. ${ }^{7}$ They are non-ionising and can give good spatial resolution of $1 \mu \mathrm{m}$ but, at that level, digital reconstruction of the image is complicated, ${ }^{8}$ whereas $40-60 \mu \mathrm{m}$ is achievable. ${ }^{9}$ To our knowledge, imaging devices are not readily available to the profession and long-term health effects are unknown.

\section{INFRA-RED (WAVELENGTHS}

\section{OF $\sim 8 \times 10^{-7}$ TO $10^{-3} \mathrm{M}$ )}

Infra-red waves are non-ionising, noninvasive and non-destructive, enabling repeat images to be taken. Portable devices are available.

This radiation may be directed at the subject as, in the near-infra-red range of $1,310 \mathrm{~nm}$, enamel is highly transparent compared to visible light, permitting the detection of demineralisation as a dark spot from increased scattering (Fig. 4). ${ }^{10,11}$ Fluorosis, stains and pigmentation are recognisable from demineralisation. ${ }^{11}$

Alternatively, the natural infra-red emissivity of a subject can also be recorded with a thermal camera operating in the $9,000 \mathrm{~nm}$ to $12,000 \mathrm{~nm}$ range. The first thermogram was produced in 1840, and the 1950s saw the first medical use. ${ }^{12}$ Temperature differentials of $0.025{ }^{\circ} \mathrm{C}$ are achievable, producing colour contrasting images with pixel resolutions of $640 \times 480$. Occlusal caries has been associated with reduced temperature compared to its surroundings. Evaporation of water from the porous demineralised area is detectable with a thermal camera (Fig. 5), ${ }^{13}$ and correlation of the lesion depth or mineral loss with surface temperature has been demonstrated. ${ }^{14}$ Sensitivity of $58 \%$ and specificity of $83 \%$ for occlusal lesions reaching the dentine has been shown. Soft-tissue lesions, such as basal cell carcinoma, can also be observed. ${ }^{15}$

However, the emissivity is a surface effect and there is low resolution of images acquired. Any fluid present (for example, saliva) will absorb the waves ${ }^{16}$ and, for the breathing subject, there is continuous fluctuation of air temperature and humidity, which hinder the accuracy of the readings. Attempts have been made to assess tooth vitality from the crown temperature but results have been inconclusive. Some studies demonstrate a higher temperature and quicker re-warm rate in vital than non-vital teeth, ${ }^{17-19}$ while others have demonstrated no detectable difference..$^{20-22}$

\section{OPTICAL COHERENCE TOMOGRAPHY (WAVELENGTHS OF $\left.\sim 10^{-7} \mathrm{M}\right)$}

Waves in the near-infra-red are split then recombined, enabling a pattern from the interference and back-scattered waves to format a 2D image of the optical reflection $^{23-25}$ and 3D real-time imaging is also achievable. It is a non-invasive, noncontact, non-ionising technique, with no biological effects to date. The chosen wavelength determines the depth of penetration and the resolution, which can reach $2.0 \mathrm{~mm}$ and 5-15 $\mu \mathrm{m}$, respectively. Uses include assessment of oral soft-tissue lesions and caries-depth with polarisation $^{26}$ (Fig. 6). ${ }^{24}$ Sensitivity for detection of squamous cell carcinoma from noncancer tissue was reported at 0.931 and specificity was the same; for squamous cell carcinoma against other pathologies sensitivity was 0.931 with specificity of

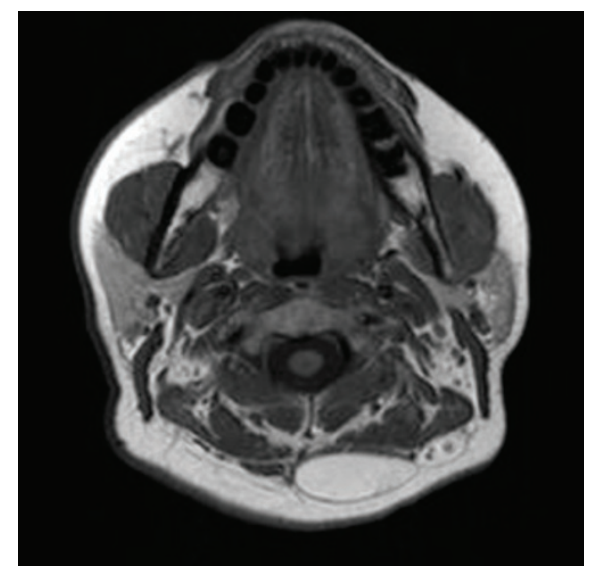

Fig. $2 \mathrm{MRI}$ of the head and neck. Evaluating a lipoma of the neck

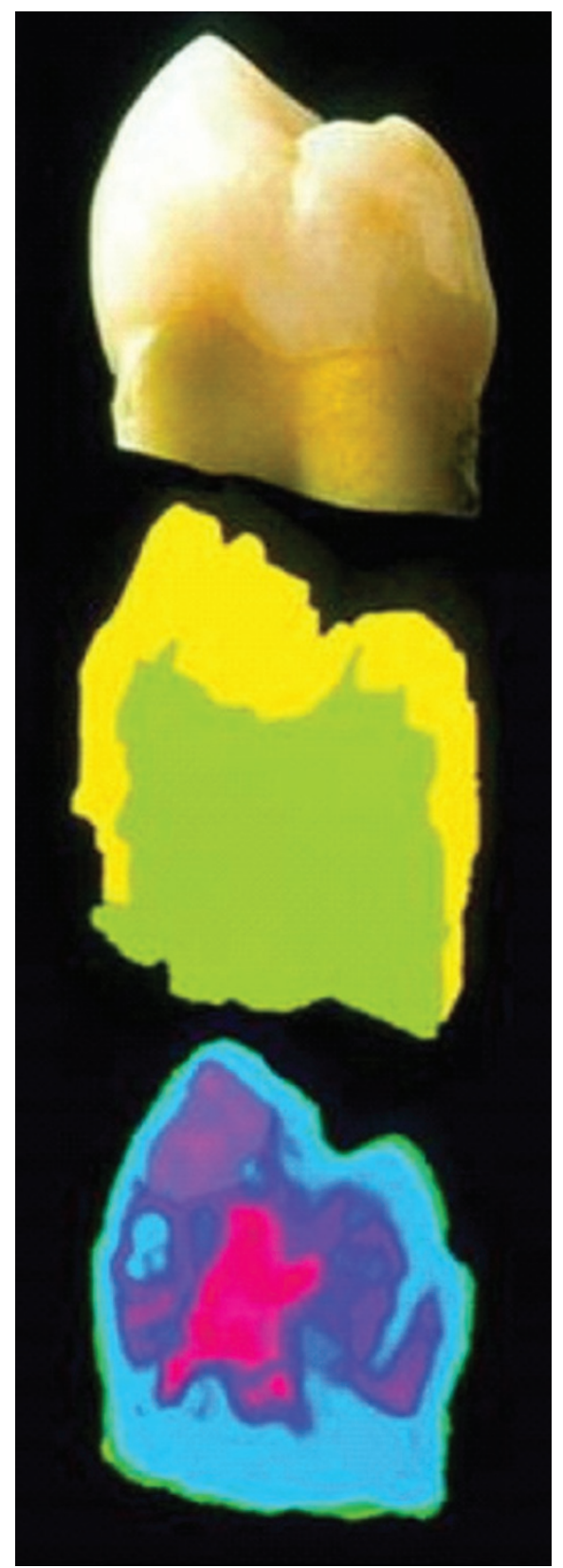

Fig. 3 Cutting edge: terahertz images of a tooth. Reprinted with permission from Macmillan Publishers Ltd: Nature News, doi:10.1038/news020506-5, copyright (2002) 

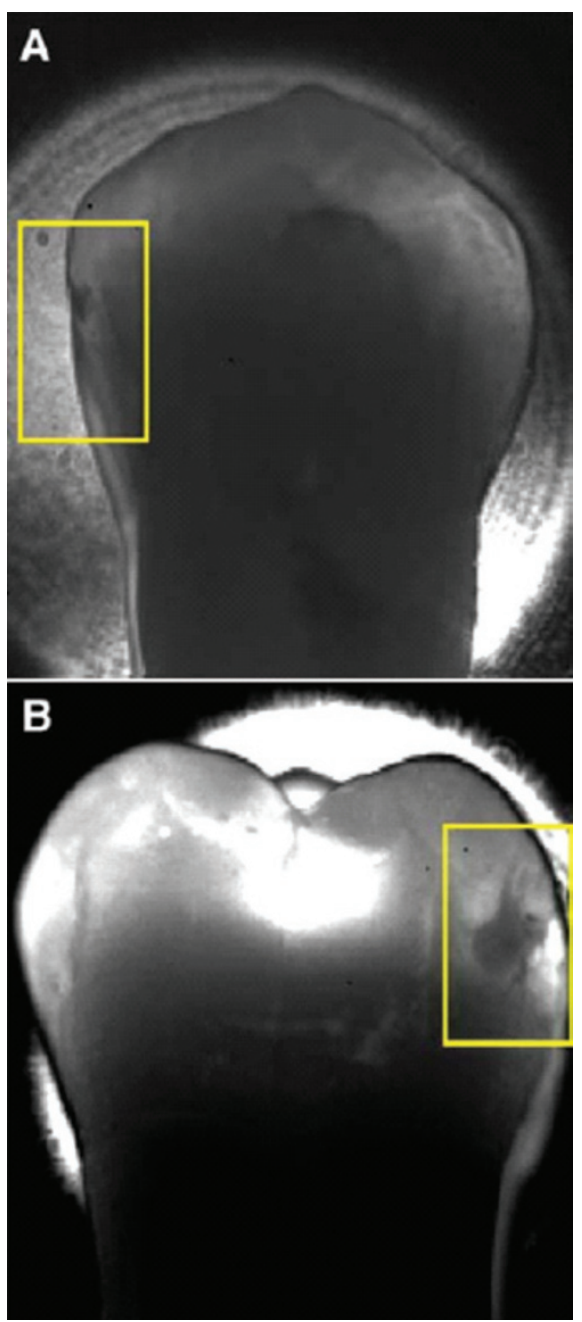

Fig. 4 NIR images of interproximal lesions. Reprinted from: Fried D, Featherstone J D B, Darling C L, Jones R S, Ngaotheppitak $P, B$ ühler C M. Early caries imaging and monitoring with near-infra-red light. Dent Clin North Am 2005; 49: 771-793 with permission from Elsevier

$0.973 .{ }^{25}$ However, the availability of the machine to the profession is a problem. ${ }^{27}$ The status of the tooth-surface needs consideration, as hydration of enamel affects signal intensity, which decreases when air is blown, ${ }^{28}$ as well as the structural orientation of dentine on the scattering of light. ${ }^{29}$

\section{LASER DOPPLER (WAVELENGTH $\left.\sim 10^{-7} \mathrm{M}\right)$}

$\operatorname{Red}^{30}$ or green ${ }^{31}$ light is used and tissue vascular supply is assessed by the Doppler effect. ${ }^{32}$ It is non-invasive, non-ionising with arbitrary units, ${ }^{33}$ which prevent comparison of successive readings. Future indications include assessment of grafts, osteomyelitis of bone and supporting-bone of dental implants. ${ }^{34}$ Unfortunately, the signal received can vary due to the location and angulation of the probe on the tooth ${ }^{35}$

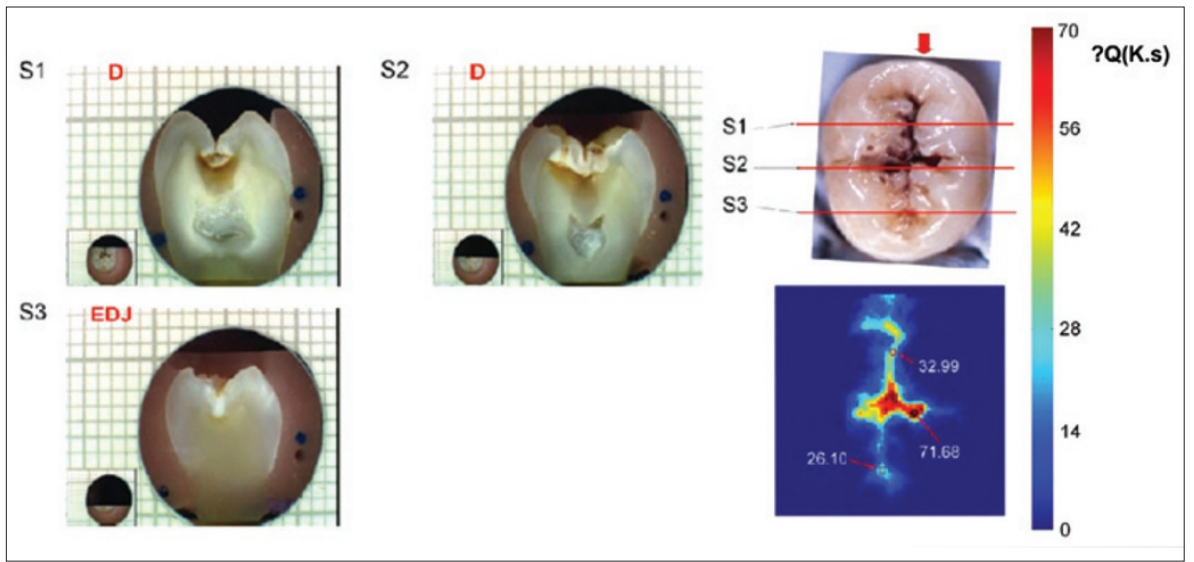

Fig. 5 Thermal image of demineralised tooth. Reprinted from: Zakian C M, Taylor A M, Ellwood R P, Pretty I A. Occlusal caries detection by using thermal imaging. J Dent 2010; 38: 788-795 with permission from Elsevier

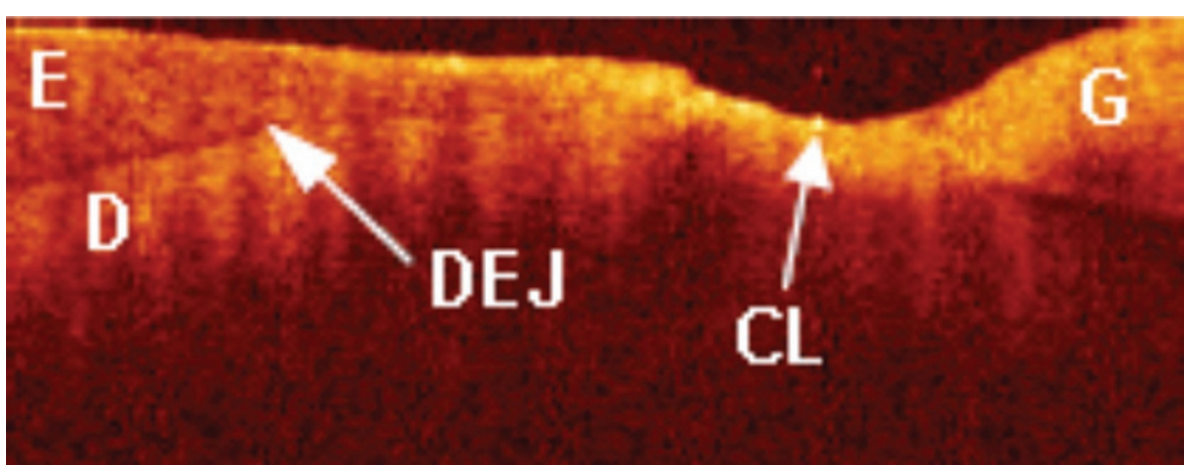

Fig. 6 Cervical caries lesion (CL) viewed by OCT. $E=$ enamel, $D=$ dentine, $D E J=$ dentine enamel junction, G = gingivae. Reprinted from: Feldchtein F I, Gelikonov G V, Gelikonov V M et al. In vivo OCT imaging of hard and soft tissue of the oral cavity. Opt Express 1998; 3: 239-250 with permission from the Optical Society

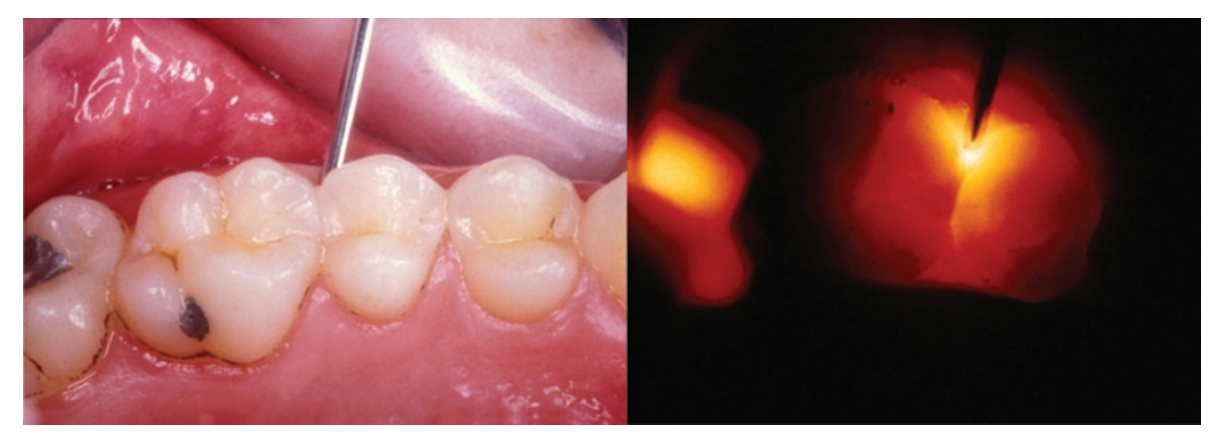

Fig. 7 FOTI image evaluating interproximal caries lesion, courtesy of A. F. Hall

and also due to the optical properties of the tooth. ${ }^{30}$ When investigating the pulpal vascular supply, there may be contamination of the signal from other vascular sources, for example, periodontal ligament, ${ }^{36}$ giving unreliable results. Its use is contra-indicated in heavily-restored dentitions.

\section{DIGITAL FIBRE OPTIC}

TRANSILLUMINATION, DIAGNODENT AND QUANTITATIVE LIGHT-INDUCED FLUORESCENCE (WAVELENGTH 400 TO 750 NM)

These diagnostic techniques draw on the visible spectrum for assessment of the mineralised coronal portion of the tooth. Fibre optic transillumination (FOTI) (Fig. 7) preceded the digital fibre optic transillumination (DiFOTI) which captures the transmitted photons from the light-source with a charge couple device (CCD), enabling the digital image to be displayed. ${ }^{37}$ Sensitivity of 14\% and specificity of 95\% for occlusal caries is reported, but proximal lesions result in 4\% sensitivity and 100\% specificity ${ }^{38}$ from FOTI. Quantitative assessment is possible from DiFOTI, with resolution of 43 pixels $/ \mathrm{mm} .{ }^{39}$ It is simple to use, nonionising and non-invasive with the ability to provide real-time images, which are a 
great education tool. However, the depth of a lesion cannot be estimated and subgingival areas are not accessible. ${ }^{40}$

DIAGNOdent uses $655 \mathrm{~nm}$ red laser light to initiate fluorescence which is possibly of microbial origin, ${ }^{41}$ captured by a photocell delivering a numerical and acoustic signal. ${ }^{42}$ It is non-ionising and simple to use but active or arrested lesions are indistinguishable. ${ }^{43}$ Sensitivity and specificity for dentinal lesions have been cited as 0.75 and 0.96 , respectively. ${ }^{44}$

Quantitative light fluorescence (QLF) uses light with a peak intensity of 370-410 nm to fluoresce the tooth and the emitted photons are captured by a CCD and digitised. ${ }^{45}$ Non-ionising, non-invasive, quick to use, but hydration of the tooth affects the results, with a stronger signal from dehydrated lesions due to increased scattering of the short-length photons. ${ }^{46}$ Accessibility can be a concern for interproximal surfaces and smooth surfaces can only be assessed to $500 \mu \mathrm{m}^{4}$ (Fig. 8), with stains and white spot lesions appearing identical. Sensitivity of 0.68 and specificity of 0.70 for occlusal caries has been achieved. ${ }^{47}$

\section{ULTRAVIOLET (UV) (WAVELENGTH OF $10^{-8}$ TO $4 \times 10^{-7} \mathrm{M}$ )}

UV light can produce fluorescence in enamel $^{48}$ which, if demineralised, will lack fluorescence but it is difficult to separate caries from developmental defects. ${ }^{49}$ UV digital viewers and camcorders use $396 \mathrm{~nm}$ UV-rays and can give resolution of $640 \times 480$ pixels. The UV-rays may be reflected or absorbed in surface layers and aid forensic medicine with detection of bitemarks and bruises ${ }^{50}$ and the fluorescence properties identify dental materials. ${ }^{51}$ Basal cell carcinomas can be recognised as dark patches and oral squamous cell carcinoma may be discerned..$^{52}$

It is non-ionising but the subject and operator need protection due to risk of cataracts and possible damage to DNA formation. ${ }^{15}$ Some subjects will be particularly sensitive to UV-rays and care is needed, for example, systemic lupus erythematous and xeroderma pigmentosa. ${ }^{53}$

\section{X-RAYS (WAVELENGTH $~ 10^{-8}$ TO $10^{-10} \mathrm{M}$ )}

$\mathrm{X}$-rays whose absorption is dependent on the tissues' atomic number $(\mathrm{Z})$ produce image contrast primarily due to the

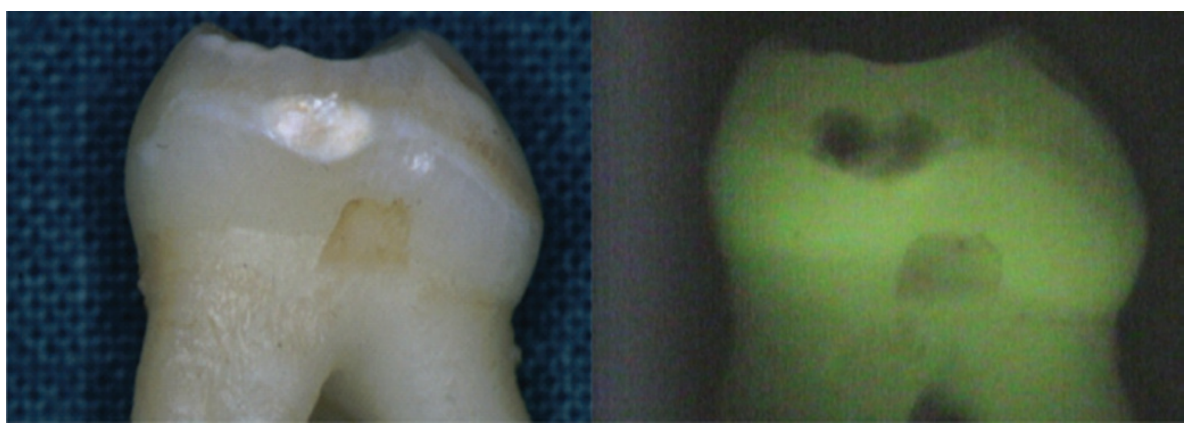

Fig. 8 QLF image evaluating caries lesions, courtesy of A. F. Hall
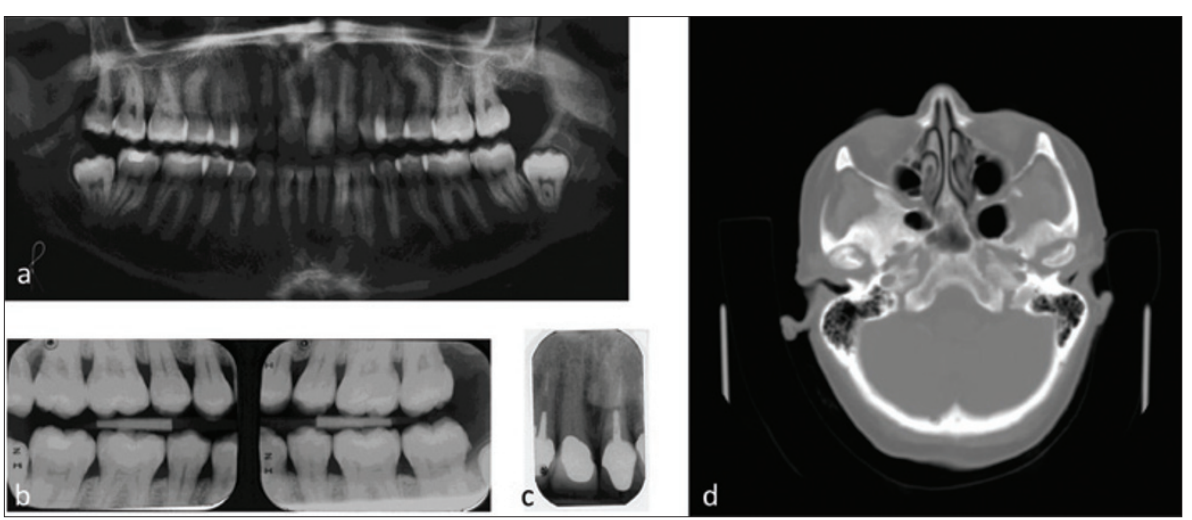

Fig. 9 A variety of radiographic images: a) Extra-oral panoramic, b) Intra-oral bitewings, c) Intra-oral periapical, d) Axial CT

photoelectric effect. An energy range of 65 to $70 \mathrm{kV}$ for intra-oral dental views, and 90 to $120 \mathrm{kV}$ for cone beam computed tomography, is employed. This yields a variety of analogue or digital images from full-field or scanning sequences (Fig. 9).

Sensitivity of 0.95 and specificity of 0.83 are reported for enhanced digital images for proximal caries detection. ${ }^{47}$ Subtraction of digital images is also possible and, when monitoring lesions, may be very useful but the geometric reproducibility needs to be exemplary. There are numerous digital detector systems available ${ }^{54}$ which convert the radiation into an electric signal which may be wired or wireless, for example, solid state (CCD and CMOS) or photostimulable phosphor plates. Considerations such as patient-comfort, image quality (for example, spatial resolution and contrast), radiation dose, speed of image production and cross-infection risk influence the operator's choice. The detector may integrate the signal over time or record every signal event. Digital detectors do compare with analogue film for spatial resolution, achieving $20 \mathrm{lp} / \mathrm{mm}$. However, $\mathrm{X}$-rays are ionising with associated detrimental health-effects, that is, somatic deterministic and stochastic, genetic stochastic. ${ }^{1}$ The geometric accuracy may lead to errors in assessment of lesion-depths, such as caries. ${ }^{42}$ Guidelines for dental radiography are shown in Table 1.

\section{TOMOGRAPHY}

Conventional tomography can deliver the single-slice dental panoramic image but, with technological advances, multipleslices of computed tomography (CT) can provide a 3D image from a CT scanner. However, the equipment is very expensive and occupies a large space. Dental cone beam CT (CBCT) - also known as digital volumetric tomography (DVT) - can use a vertically-positioned patient, reducing the space requirement compared to the horizontal CT scan. This is available and affordable to the general dental practitioner. Spatial resolution of between $0.07-0.4 \mathrm{~mm}^{55,56}$ with isotropic voxels is possible with СВCT. CT voxels may be anisotropic or isotropic. Multi-slice CT may deliver equivalent resolution from equivalent dose compared to $\mathrm{CBCT}^{56}$ but it has also been stated СВCT can deliver reduced effective dose (Table 2) ${ }^{57,58}$ Both $\mathrm{CT}$ and $\mathrm{CBCT}$ can have an adjustable field of view (FoV).

CT has been used for assessing intracranial disease and damage following trauma to the head and neck, facial fractures, 


\section{Table 1 Guidelines for selection criteria in dental radiography}

\begin{tabular}{|c|c|c|c|}
\hline DPT & Bitewing radiographs & eriapical radiographs & Cone beam CT \\
\hline $\begin{array}{l}\text { Incomplete demonstration of a } \\
\text { bony lesion of unerupted tooth } \\
\text { on an intra-oral radiograph } \\
\text { Grossly neglected mouth with } \\
\text { multiple visible carious lesions } \\
\text { Established periodontitis and } \\
\text { pocketing of } 6 \text { mm or more, } \\
\text { where a dose advantage possible } \\
\text { over intra-oral radiographs } \\
\text { Assessment of third molars prior } \\
\text { to planned surgical intervention } \\
\text { Orthodontic assessment where } \\
\text { there is a clinical need to view } \\
\text { the developing dentition } \\
\text { Assessment for mandibular } \\
\text { fractures } \\
\text { Pre-implant assessment of } \\
\text { alveolar bone } \\
\text { Destructive diseases of the } \\
\text { articular surfaces of the TMJ }{ }^{b} \\
\text { Antral disease - floor, posterior } \\
\text { and medial walls }\end{array}$ & $\begin{array}{l}\text { Detection of caries: } \\
\text { High risk - } 6 \text { month intervals } \\
\text { until no new or active lesions } \\
\text { detected } \\
\text { Moderate risk - annually } \\
\text { until no new or active lesions } \\
\text { detected } \\
\text { Low risk - } 12-18 \text { months } \\
\text { in deciduous dentition and } \\
2 \text {-yearly in permanent dentition } \\
\text { Monitoring progression of } \\
\text { caries }^{b} \\
\text { Assessment of existing } \\
\text { restorations } \\
\text { Assessment of periodontal } \\
\text { status }^{b} \\
\text { Horizontal BW if uniform } \\
\text { pocketing }<6 \text { mm with little or } \\
\text { no recession } \\
\text { Vertical BW if pocketing } \geq 6 \text { mm } \\
\text { and supplemented with PA } \\
\text { when alveolar bone not visible }\end{array}$ & $\begin{array}{l}\text { Assessment of apical infection/inflam- } \\
\text { mation and periodontal status }{ }^{b} \text { prior to } \\
\text { tooth preparation for: } \\
\text {-crown } \\
\text {-bridge retainer } \\
\text {-denture abutment } \\
\text { 2-10 years after preparation of a crown } \\
\text { or bridge abutment but, if root-filled, } \\
1 \text { yeara } \\
\text { Prior to surgical and non-surgical } \\
\text { endodontic treatment (2 may be } \\
\text { required for Parallax) } \\
\text { If an apex-locator is unavailable, a } \\
\text { working-length radiograph is justified } \\
\text { Endodontic Master Point and immedi- } \\
\text { ately post-obturation } \\
1 \text { year post-endodontic treatment and } \\
\text { if of uncertain outcome reassess until } \\
\text { resolved or for a minimum of } 4 \text { yearsc } \\
\text { Prior to vital pulp-capping and pulp } \\
\text { amputations, at } 6 \text { months post-treat- } \\
\text { ment and annually until root-forma- } \\
\text { tion is complete } \\
\text { Presence and position of unerupted } \\
\text { teeth } \\
\text { Trauma to teeth and supporting } \\
\text { alveolar bone } \\
\text { Evaluation of root morphology prior to } \\
\text { extractions } \\
\text { Assessment of apical cysts and alveolar } \\
\text { bone-lesions }{ }^{b} \\
\text { Assessment of implants }{ }^{b}\end{array}$ & $\begin{array}{l}\text { Is indicated for selected cases of: } \\
\text { Dental trauma, eg root fracture, when conventional } \\
\text { radiographs fail to provide adequate information for } \\
\text { treatment planning } \\
\text { Implant placement as an alternative cross-sectional } \\
\text { technique with lower radiation dose } \\
\text { Orthognathic surgery-planning } \\
\text { May be indicated for: } \\
\text { Localised assessment of an impacted tooth, including } \\
\text { assessment of resorption of the adjacent tooth } \\
\text { Infra-bony defects and furcation lesions } \\
\text { Periapical assessment when conventional radio- } \\
\text { graphs are inconclusive of patient's symptoms } \\
\text { Evaluation of root-canal anatomy inadequately } \\
\text { demonstrated by conventional radiographs } \\
\text { Surgical endodontics for assessing proximity of } \\
\text { anatomical structures } \\
\text { Root-resorption if } 3 D \text { information could alter the } \\
\text { management or prognosis } \\
\text { Endodontics complicated by resorption, perio/endo } \\
\text { lesions, perforations and atypical pulp anatomy } \\
\text { Assessment of third molars and proximity of the } \\
\text { mandibular canal prior to surgical intervention } \\
\text { Pre-surgical assessment of an unerupted tooth if } \\
\text { conventional radiography proves inadequate } \\
\text { Evaluation of bony invasion of the jaws by oral } \\
\text { carcinomad } \\
\text { Is preferred to MscT if radiation dose is lower for } \\
\text { assessment of: } \\
\text { Impacted teeth, including assessment of resorption } \\
\text { of the adjacent tooth } \\
\text { Cleft palate } \\
\text { Maxillofacial fractures } \\
\text { Complex skeletal abnormalities with combined ortho- } \\
\text { dontic/surgical management } \\
\text { TMJd }\end{array}$ \\
\hline
\end{tabular}

. Faculty of General Dental Practitioners (UK), The Royal College of Surgeons of England. Selection criteria for dental radiography, 2004. b. Whaites E. Essentials of dental radiography and radiology, 4th ed. Churchill Livingstone Elsevier, 2012.

c. European Society of Endodontology. Quality guidelines for endodontic treatment: consensus report of the European Society of Endodontology. Int Endod J 2006; 39: 921-930. d. Radiation Protection No 172. Cone beam CT for dental and maxillofacial radiology. Evidence-based guidelines, 2012.

tumour-staging in the head and neck, implant-planning and investigating the $\mathrm{TMJ}^{1}$ but, with a possible reduction in effective radiation dose, CBCT may be more appropriate in some situations, for example, implant-planning. Other uses of CBCT may include: assessment of dento-alveolar pathology, maxillofacial surgery, orthodontics, nerve-position, endodontics, periodontics and general and forensic dentistry. ${ }^{59}$

Measurement accuracy of CBCT can be good (within 1 pixel longitudinally and up to 2.35 pixels horizontally ${ }^{60}$ ) with good geometric accuracy (mean deviations $0.13 \pm 0.09 \mathrm{~mm}$ from three coordinate axes $^{61}$ ). However, with increasing voxel size there can be a tendency to underestimate volumetric measurements which can become significant above $300 \mu \mathrm{m} .{ }^{62}$

\section{Table 2 Effective radiation doses for dental radiography}

\begin{tabular}{l|l|} 
Radiographic technique & Effective dose $\mu$ Sv (median value $\mu$ Sv) \\
\hline $\begin{array}{l}\text { Intra-oral radiograph } \\
\text { (F-speed or PSP with rectangular collimation) }\end{array}$ & $<1.5$ \\
\hline Dental panoramic tomograph & $2.7-24.3$ \\
\hline $\begin{array}{l}\text { Dental CBCT: } \\
\text { Dento-alveolar with a field of view height }<10 \mathrm{~cm}\end{array}$ & $11-674(61)$ \\
$\begin{array}{l}\text { Craniofacial with a field of view height }>10 \mathrm{~cm} \\
\text { Dento-alveolar 10-year-old phantom } \\
\text { Craniofacial 10-year-old phantom } \\
\text { Dento-alveolar adolescent phantom } \\
\text { Craniofacial adolescent phantom }\end{array}$ & $30-1073(87)$ \\
& $11-214(43)$ \\
\hline Multi-slice CT maxillomandibular & $18-70(32)$ \\
\hline $\begin{array}{l}\text { Radiation Protection No } 172 . \text { Cone beam CT for dental and } \\
\text { maxillofacial radiology. Evidence-based guidelines, 2012. }\end{array}$ & $81-216(135)$ \\
\hline
\end{tabular}

Many manufacturers market CBCT machines, each with their own limitations, and there is a need to establish image-quality criteria, irrespective of machine..$^{58}$
CBCT also has increased noise and scatter, leading to less soft-tissue contrast than CT. ${ }^{55}$ Additional limitations of CBCT include: arbitrary greyscale values ${ }^{63}$ streak 
or star artefacts from metallic objects (for example, amalgam restorations, reducing diagnostic yield ${ }^{64}$ ) and motion artefacts. The motion may be unavoidable due to respiration and cardiac rhythm or to headtremor ${ }^{65}$ and needs further research to enable correction during image reconstruction.

The scan settings (for example, FoV, resolution and X-ray parameters) determine effective dose ${ }^{66}$ which may vary by a factor of 4.6 to 5.2 from the lowest to highest $\operatorname{dose}^{67}$ and can influence whether sensitive organs are inside or outside the direct beam. This influences image quality and diagnostic potential of the CBCT image. A more standardised approach is needed to achieve the 'as low as reasonably achievable' dose ${ }^{68}$ Copper filtration can reduce effective dose by $43 \%$ with adjusted $\mathrm{kVp}^{69}$ without loss of image quality. The use of collimation and patient protection has been suggested to minimise dose to structures such as the eyes and thyroid. ${ }^{70}$ However, the thyroid should not be in the primary beam.

For dental applications imaging high and medium-contrast tissues, CBCT may be the correct choice compared to $\mathrm{CT}$ but the profession needs to review CBCT guidelines regularly.

\section{FUTURE DEVELOPMENTS FOR X-RAYS}

\section{Phase contrast}

On entry through tissue, $\mathrm{X}$-rays refract like light waves through glass and the index of refraction deviates from 1 , that is, unity:

$$
\begin{aligned}
\mathrm{n}= & 1-\delta-i \beta \\
\mathrm{n}= & \text { index of refraction } \\
\delta= & \text { phase shift incorporating the } \\
& \text { refractive effects } \\
i \beta= & \text { absorption of incident rays }
\end{aligned}
$$

This will result in a loss of coherence of the waves generating a shift in wave phase. The refractive proportion is greater than the absorption component normally used to assemble an image and if captured can exhibit detail not currently achievable (Figs 10 and 11). ${ }^{71,72,73}$ This can operate at the higher energy levels of X-rays, reducing exposure of the subject but achieving greater image contrast. The greatest contrast is seen with soft-tissues, not the mineralised tissue. ${ }^{73}$

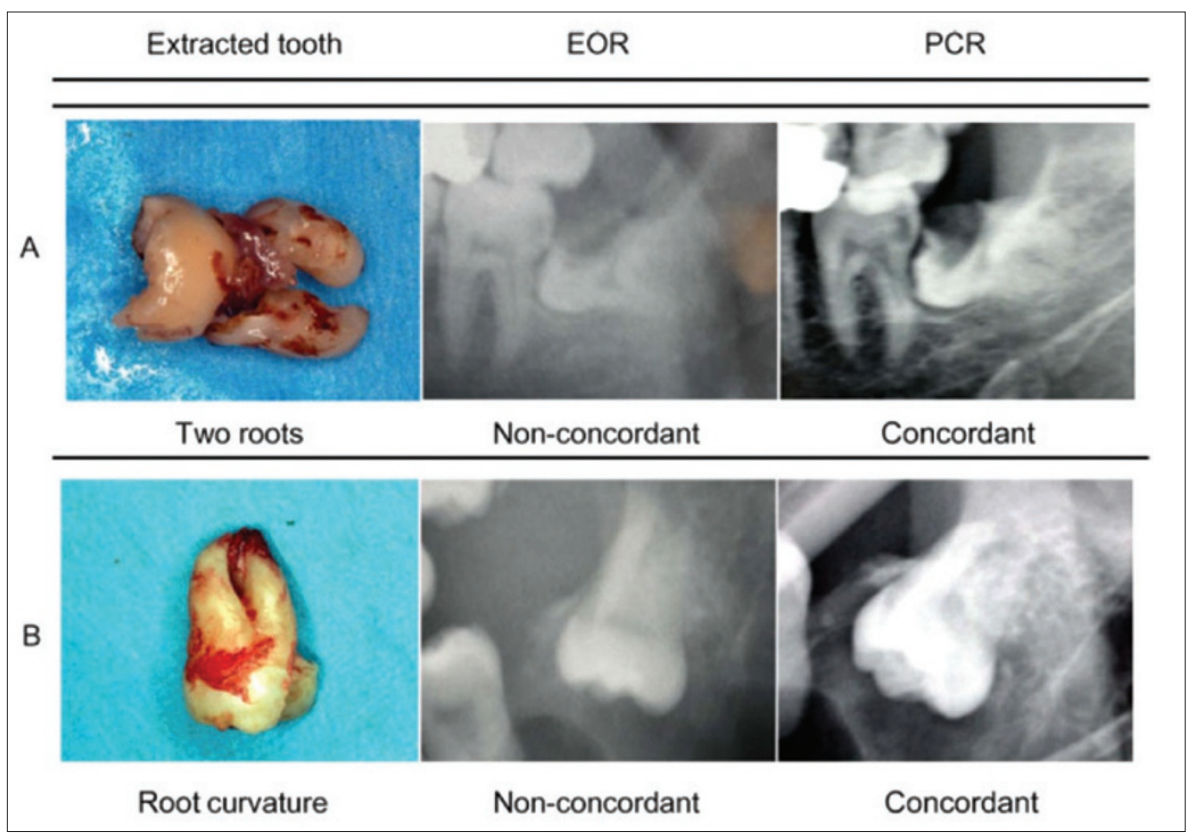

Fig.10 Phase-contrast radiography - evaluating root morphology. Reprinted from: Sato $A$, Nakamoto N, Abe T, Fukushima Y, Tomaru Y, Sakata Y, et al. Preliminary Results of a Study Comparing Conventional Radiography with Phase-contrast Radiography for Assessing Root Morphology of Mandibular Third Molars. Dentomaxillofacial Radiology 2011; 40: 91-95.
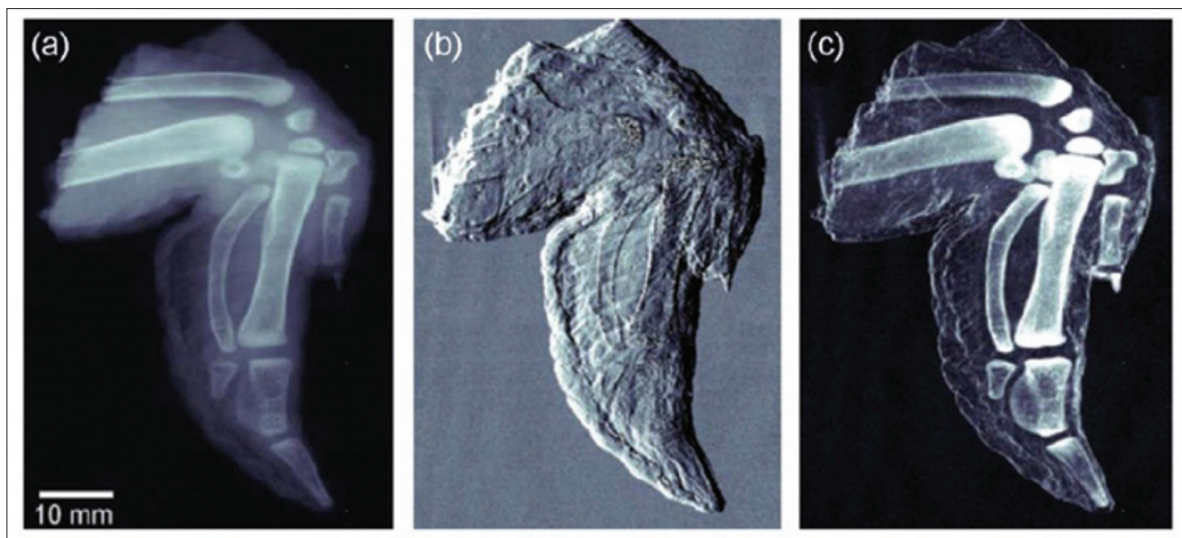

Fig. 11 Post-mortem images of a chicken wing. a) Conventional transmission image, b) differential phase-contrast image, c) dark-field image. Reprinted from: Bech $M$, Jensen T H, Bunk $\mathbf{O}$ et al. Advanced contrast modalities for $\mathrm{X}$-ray radiology: phase-contrast and dark-field imaging using a grating interferometer. Z Med Phys 2010; 20: 7-16 with permission from Elsevier

Sophisticated equipment is required to produce the phase contrast of the waves, for example, a synchrotron, which was unacceptable clinically due to size and cost, and historically crystals split the beams to enable phase differences, but these were unstable and gave a small field of view. Micro-focus X-ray tubes are being successfully operated to generate the beam but also have limited field of view. ${ }^{74} \mathrm{X}$-ray interferometery is now achievable by exposing the beam to a series of gratings. One grating is located close to the wavesource (source-grating) before the subject, and two gratings are positioned after the subject. These are described as a phasegrating and absorption-grating, respectively. The phase-contrast is generated by the last two gratings which are strategically placed to produce a linear periodic fringe pattern which is aligned with the absorption grating placed in front of the detector. ${ }^{73}$ Changes in oscillations within the detector when the gratings are scanned are assessed according to subject. These signals are digitised to generate the phase contrast image for analysis.

\section{DARKFIELD}

$\mathrm{X}$-ray grating interferometry, as described above, is actually a multimodal imaging technique and can be drawn on to fabricate not only the absorption and phase-contrast image but also the darkfield image. ${ }^{73}$ The darkfield image, as with visible light, is manufactured from the 


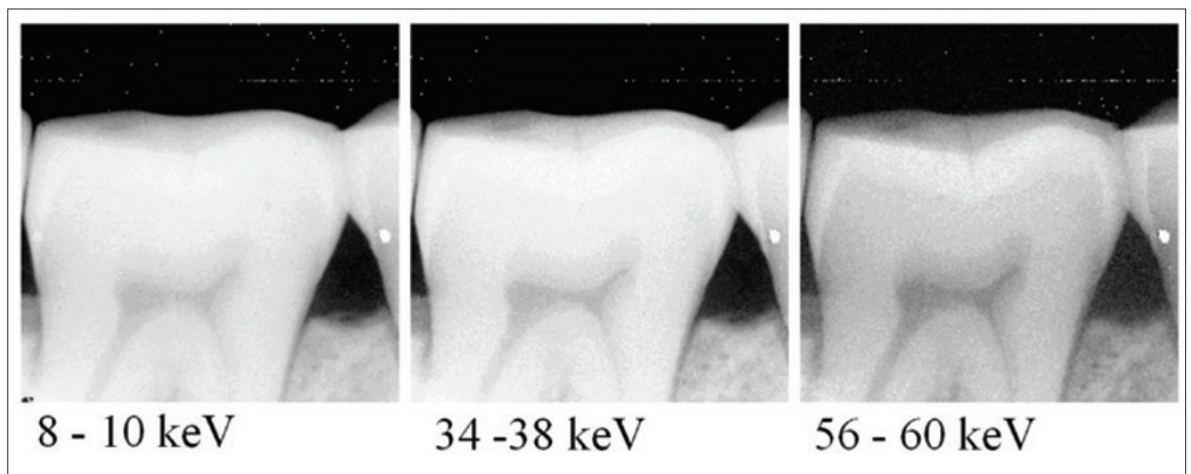

Fig. 12 Energy dependent spectral dental images. Reprinted from: Norlin B, Fröjdh C. Energy Dependence in Dental Imaging with Medipix2. In Nuclear Instruments and Methods in Physics Research Section A: Accelerators, Spectrometers, Detectors and Associated Equipment. pp 19-23. Proceedings of the 6th International Workshop on Radiation Imaging Detectors, 2005.

scattered X-rays. The image contrast is created by the small angle scattering of the waves generated from a conventional $\mathrm{X}$-ray tube source. The detector, which is a technological achievement, has the capacity to detect the scattered waves and decipher the unscattered waves which can be removed. The greater the scatter, the greater the contrast of the image and this is seen with the mineralised tissue (Fig. 11c). ${ }^{73}$ Directional darkfield imaging has been demonstrated on a dry slice of tooth. ${ }^{75}$ This allows structural information smaller than the image resolution and maximises the different angles created by the scattered rays.

The detector will primarily register the perpendicular scattered waves in darkfield imaging but, in directional darkfield, the actual angle of the scattered wave is analysed as well. Dentine showed the strongest signal and the strength of the signal decreases with increasing distance from the pulp-chamber. This may correlate with the dentinal tubules, as enamel which is a reasonably homogenous mineralised tissue, generated little scatter signal. Whether this will actually happen with a vital tooth with dentinal fluid remains to be seen, as this equipment is not currently available to the profession. Is it feasible to hypothesise that selective demineralisation of enamel prisms in the early carious lesion would induce greater scattering enabling detection?

Future developments of three dimensional darkfield images require technological furtherance but, with the ability to capture the data to produce the absorption, phase-contrast and darkfield image, the potential improvement in diagnostic yield is vast.

\section{SPECTRAL}

Initially proposed in $1976^{76}$ spectral imaging exploits the energy spectrum of $\mathrm{X}$-rays. Manipulation of X-rays has enabled the production of specific incident energy spectrums (spectral shaping) and detection of photons in specific energy bands (spectral imaging). ${ }^{77}$

An energy-dependent detector charts the charge release from incoming photons and, the higher the energy, the higher the weighting documented. This improves the resolution of the image. Counting of each individual photon in a set energy range is possible (Fig. 12) ) $^{78}$ and eliminates any weighting for the higher energies, again increasing the image resolution.

The scanning beam method is beneficial for the subject, as the majority of scatter is blocked. In addition, the actual number of photons produced interacting with the patient's tissue is reduced. Transmitted information needs to be accurately and efficiently detected by X-ray optics, capillary optics or an array of refractive $\mathrm{X}$-ray lenses.

Comparison between photon-counting detectors (for example, Medipix1) and CCD used within dentistry for diagnostic imaging, demonstrated dose reductions without loss of resolution contrast. ${ }^{79}$ Further research revealed an increase in contrast of $18 \%$ is possible with the Medipix2. ${ }^{78}$

Characterisation of tissue-type (Fig. 13) and element enhancement for contrast studies $^{80}$ from the energy of the detected photons (spectral imaging) is feasible. This is due to each tissue-type having its own signature because of its atomic number (Z). ${ }^{81,82}$ This enables optimising the incident beam energy for a chosen tissue (spectral shaping $)^{83}$ which can reduce the dose to

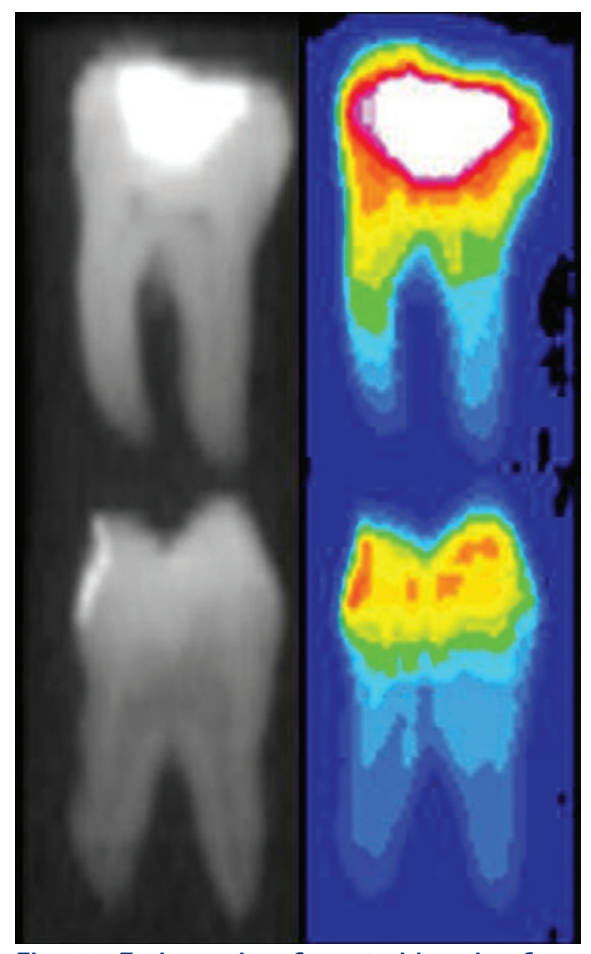

Fig. 13 Early results of spectral imaging from Medical Physics Department, Leeds Teaching Hospitals. 1) Conventional X-ray, 2) spectral image (each colour highlights a tissue-type)

the patient from non-informative low- and high-energy photons.

The possible benefits of spectral imaging include:

- Energy weighting

- Dual energy subtraction

- Identify tissue and quantify it.

This system is not currently commercially available to the dental profession.

\section{GAMMA RAYS (WAVELENGTH $\sim 10^{-13}$ TO $10^{-10} \mathrm{M}$ )}

A radioisotope, for example, technetium ( ${ }^{99 \mathrm{~m}} \mathrm{Tc}$ ) is obligatory, usually amalgamated with a pharmaceutical and administered intravenously or orally. The radioisotopes nuclei are unpredictably volatile and spontaneously disintegrate, producing gamma rays, making the patient the provenance of ionising radiation. A specialised gamma camera captures the emitted radiation to produce the image, for example, single photon emission computed tomography (2D - scintigraphy, slices - SPECT) or positron emission tomography (PET) which employs two photons from the annihilation radiation. A functional image can be generated, enabling all tissues to be assessed from one visit and recognising physiological change before anatomical 
change. ${ }^{84}$ However, resolution is poor. ${ }^{85}$ Anatomical location can improve accuracy by superimposition of a PET scan with a CT or MRI Scan. ${ }^{86,87}$

It is expensive, time-consuming and the images, unfortunately, are not diseasespecific. The radiation dose is substantial following intravenous administration of radioisotope (5-7 $\mathrm{mSv}$ and, when combined with CT scanning, approximately $25 \mathrm{mSv}){ }^{88}$ Dental restorations can produce artefacts ${ }^{89}$ and it is used for diagnosis of osteomyelitis, osteoblastic metastatic tumours, Paget's disease (Fig. 14) and salivary gland function.

Ultrasound does not employ waves from the electromagnetic spectrum and is not discussed within the remit of this article.

\section{SUMMARY}

The use of computer technology has enhanced imaging techniques, as shown with the development of the digital image and detector, for example, Medipix, along with the accessible stable beam sources for the production of phase contrast, darkfield and spectral imaging. Not all techniques are available to the clinician yet but they indicate what the future may hold. It must be remembered that technology may also be the limiting factor for any imaging technique. Signals may be received and converted to digital images but the monitor they are viewed on may not resolve adequately, with loss of diagnostic information..$^{54}$ The format the images are stored in may lead to loss of data, as well. The correct environment and setting for viewing the images must be rigidly observed, ${ }^{90}$ which leads to operator capabilities. There needs to be quality control, not just for the acquisition of images, but also for those undertaking the reporting of the image. ${ }^{91}$

\section{CONCLUSION}

Non-ionising imaging techniques, for example, infra-red, are becoming more commensurate with traditional radiographic techniques as technology progresses, and need further exploration. Nevertheless, X-rays continue to be the leading diagnostic image for dentists and are being nurtured for improved diagnostic potential with elevated contrast and resolution with reduced doses, hopefully diminishing the potential health-risk to our patients.

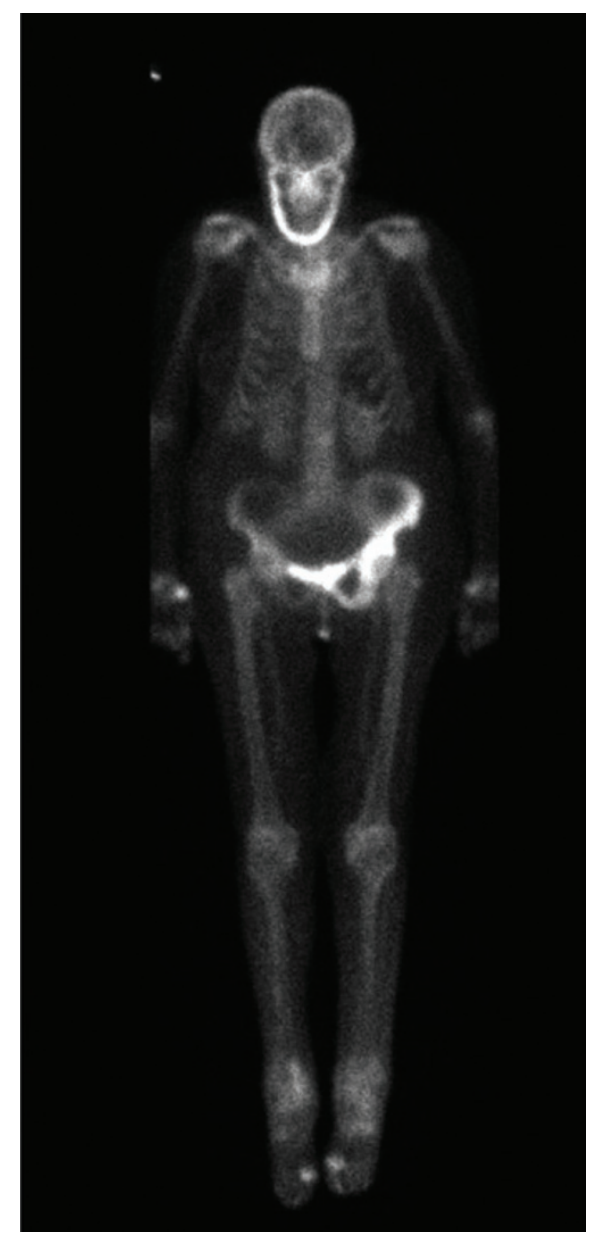

Fig. 14 Single plane nuclear medicine image demonstrating Paget's disease affecting the mandible

1. Whaites E. Essentials of dental radiography and radiology, 4th ed. Edinburgh: Churchill, Livingstone, 2007.

2. Idiyatullin D, Corum C, Moeller S, Prasad H S, Garwood M, Nixdorf D R. Dental magnetic resonance imaging: making the invisible visible. J Endod 2011; 37: 745-752.

3. Yanagi Y, Asaumi Ji, Unetsubo T et al. Usefulness of MRI and dynamic contrast-enhanced MRI for differential diagnosis of simple bone cysts from true cysts in the jaw. Oral Surg Oral Med Oral Pathol Oral Radiol Endod 2010; 110: 364-369.

4. Hall A, Girkin J M. A review of potential new diagnostic modalities for caries lesions. J Dent Res 2004; 83 Spec No C: C89-C94.

5. Wilmink G J, Ibey B L, Tongue T et al. Development of a compact terahertz time-domain spectrometer for the measurement of the optical properties of biological tissues. J Biomed Opt 2011; 16: 047006.

6. Ball P. Laser vision plugs gap. Nature. 9 May 2002. Available at: www.nature.com/news/2002/020509/ full/news020506-5.html (accessed June 2013).

7. Crawley D A, Longbottom C, Cole B E et al. Terahertz pulse imaging: a pilot study of potential applications in dentistry. Caries Res 2003; 37: 352-359.

8. Ferguson B, Wang S, Grey D, Abbott D, Zhang X C. Identification of biological tissue using chirped probe $\mathrm{THz}$ imaging. Microelectronics J 2002 33: 1043-1051.

9. Churchley D, Lynch R J M, Lippert F, Eder J S O B Alton J, Gonzalez-Cabezas C. Terahertz pulsed imaging study to assess remineralization of artificial caries lesions. J Biomed Opt 2011; 16: 026001.

10. Staninec $M$, Lee $C$, Darling $C L$, Fried $D$. In vivo nearIR imaging of approximal dental decay at $1,310 \mathrm{~nm}$ Lasers Surg Med 2010; 42: 292-298.

11. Fried D, Featherstone J D B, Darling C L, Jones R S, Ngaotheppitak P, Buhler C M. Early caries imaging and monitoring with near-infrared light. Dent Clin North Am 2005; 49: 771-793.

12. Ammer $\mathrm{K}$, Ring E F J (eds). The thermal image in medicine and biology. Proceedings of the Meeting of the Royal Photographic Society Imaging Science and Technology Group and the 6th European Congress of Thermology. Wein: Uhlen Verlag, 1994.

13. Zakian C M, Taylor A M, Ellwood R P, Pretty I A. Occlusal caries detection by using thermal imaging. J Dent 2010; 38: 788-795.

14. Kaneko K, Matsuyama K, Nakashima S. Quantification of early carious enamel lesions by using an infrared camera in-vitro. pp 83-100. In Stookey G K (ed) 4th Annual Indiana conference, 1999

15. Flores-Sahagun J H, Vargas J V C, Mulinari-Brenner FA. Analysis and diagnosis of basal cell carcinoma (BCC) via infrared imaging. Infrared Phys Technology 2011; 54: 367-378.

16. Kateb B, Yamamoto V, Yu C, Grundfest W S, Gruen $J$ P. Infrared thermal imaging: a review of the literature and case report. Neuroimage 2009; 47: T154T162.

17. Banes J D, Hammond H L. Surface temperatures of vital and nonvital teeth in humans. J Endod 1978; 4: 106-109.

18. Fanibunda K. Diagnosis of tooth vitality by crown surface temperature measurement: a clinical evaluation. J Dent 1986; 14: 160-164.

19. Pogrel M, Yen C, Taylor R. Studies in tooth crown temperature gradients with the use of infrared thermography. Oral Surg Oral Med Oral Pathol 1989; 67: 583-587.

20. Crandell C E, Hill R P. Thermography in dentistry: a pilot study. Oral Surg Oral Med Oral Pathol 1966; 21: 316-320.

21. Kells B E, Kennedy J G, Biagioni P A, Lamey P J. Computerized infra-red thermographic imaging and pulpal blood flow: Part 2. Re-warming of healthy human teeth following a controlled cold stimulus. Int Endod J 2000; 33: 448-462.

22. Smith $E$, Dickson $M$, Evans $A$, Smith D, Murray $C$. An evaluation of the use of tooth temperature to assess human pulp vitality. Int Endod J 2004; 37: 374-380.

23. Colston B W Jr, Everett $M J$, Da Silva $L B$, Otis $L L$, Stroeve $P$, Nathel $H$. Imaging of hardand soft-tissue structure in the oral cavity by optical coherence tomography. Appl Opt 1998; 37: 3582-3585.

24. Feldchtein F I, Gelikonov G V, Gelikonov V M et al. In vivo OCT imaging of hard and soft-tissue of the oral cavity. Opt Express 1998; 3: 239-250.

25. Wilder-Smith P, Holtzman J, Epstein J, Le A. Optical diagnostics in the oral cavity: an overview. Oral Dis 2010; 16: 717-728.

26. Natsume $Y$, Nakashima S, Sadr A, Shimada Y, Tagami J, Sumi Y. Estimation of lesion progress in artificial root caries by swept source optical coherence tomography in comparison to transverse microradiography. J Biomed Opt 2011; 16: 071408.

27. Wiggin L. Availability of optical coherence tomography. J Am Dent Assoc 2010; 141: 16; author reply 16 .

28. Shimamura $Y$, Murayama R, Kurokawa $H$, Miyazaki $M$, Mihata $Y$, Kmaguchi S. Influence of toothsurface hydration conditions on optical coherence tomography imaging. J Dent 2011; 39: 572-577.

29. Hariri I, Sadr A, Shimada Y, Tagami J, Sumi Y. Effects of structural orientation of enamel and dentine on light attenuation and local refractive index: an optical coherence tomography study. J Dent 2012; 40: 387-396.

30. Jafarzadeh H. Laser Doppler flowmetry in endodontics: a review. Int Endod J 2009; 42: 476-490.

31. Murray A K, Gorodkin R E, Moore T L, Gush R J, Herrick A L, King T A. Comparison of red and green laser doppler imaging of blood flow. Lasers Surg Med 2004; 35: 191-200.

32. Gazelius $B$, Edwall L O B, Edwall L. Non-invasive recording of blood flow in human dental pulp. Endod Dent Traumatol 1986; 2: 219-221.

33. Matthews B, Vongsavan N. Advantages and limitations of laser doppler flow meters. Int Endod J 1993; 26: 9-10.

34. Roeykens H, De Moor R. The use of laser Doppler flowmetry in paediatric dentistry. Eur Arch Paediatr 
Dent 2011; 12: 85-89.

35. Odour T M, Ford T R, McDonald F. Effect of probe design and bandwidth on laser Doppler readings from vital and root-filled teeth. Med Eng Phys 1996; 18: 359-364

36. Soo-ampon S, Vongsavan N, Soo-ampon M Chuckpaiwong S, Matthews B. The sources of laser Doppler blood-flow signals recorded from human teeth. Arch Oral Biol 2003; 48: 353-360.

37. Bin-Shuwaish M, Yaman P, Dennison J, Neiva G. The correlation of DIFOTI to clinical and radiographic images in Class II carious lesions. J Am Dent Assoc 2008; 139: 1374-1381.

38. Bader J D, Shugars D A, Bonito A J. A systematic review of the performance of methods for identifying carious lesions. J Public Health Dent 2002; 62: 201-213.

39. Schneiderman A, Elbaum M, Shultz T, Keem $\mathrm{S}$, Greenebaum M, Driller J. Assessment of dental caries with Digital Imaging Fiber-Optic Translllumination (DIFOTI): in-vitro study. Caries Res 1997; 31: 103-110.

40. Pretty I A, Maupomé G. A closer look at diagnosis in clinical dental practice: part 5. Emerging technologies for caries detection and diagnosis. J Can Dent Assoc 2004; 70: 540

41. Hibst R, Paulus R. Caries detection by red excited fluorescence: investigations on fluorescence. Caries Res 1999; 33: 295.

42. Yang J, Dutra V. Utility of radiology, laser fluorescence, and transillumination. Dent Clin North Am 2005; 49: 739-752.

43. Tam LE, McComb D. Diagnosis of occlusal caries: Part II. Recent diagnostic technologies. J Can Dent Assoc 2001; 67: 459-463.

44. Shi X O, Tranaeus S, Angmar-Mansson B. Validation of DIAGNOdent for quantification of smoothsurface caries: an in vitro study. Acta Odontol Scand 2001; 59: 74-78.

45. Amaechi B T. Emerging technologies for diagnosis of dental caries: the road so far. J Appl Phys 2009; 105: 102047

46. van der Veen $\mathrm{M}$, de Josselin, de Jong $\mathrm{E}$ et al. Caries activity detection by dehydration with quantitative light fluorescence. pp 251-259. Indiana: Proceedings of the 4th Annual Indiana Conference, Indianapolis, 1999

47. Pretty | A. Caries detection and diagnosis: novel technologies. J Dent 2006; 34: 727-739.

48. Benedict H C. A note on the fluorescence of teeth in ultra-violet rays. Science 1928; 167: 442

49. Angmar-Mansson B, ten Bosch J J. Optical methods for the detection and quantification of caries. $A d v$ Dent Res 1987; 1: 14-20.

50. Metcalf R D. Yet another method for marking incisal edges of teeth for bitemark analysis. $J$ Forensic Sci 2008; 53: 426-429.

51. Hermanson A S, Bush M A, Miller R G, Bush P J. Ultraviolet illumination as an adjunctive aid in dental inspection. J Forensic Sci 2008; 53: 408-411.

52. Onizawa K, Yoshida H, Saginoya H. Chromatic analysis of autofluorescence emitted from squamous cell carcinomas arising in the oral cavity: preliminary study. Int J Oral Maxillofac Surg 2000; 29: $42-46$.

53. Guidelines on the use of ultraviolet radiation in Dentistry. Commission on Dental materials, Instruments, Equipment and Therapeutics. Int Dent J 1979; 29: 61-71.

54. Farman A G, Farman T T. A comparison of 18 different $x$-ray detectors currently used in dentistry. Oral Surg Oral Med Oral Pathol Oral Radiol Endod 2005; 99: 485-489.
55. Patcas $R$, Markic $G$, Muller L et al. Accuracy of linear intra-oral measurements using cone beam $\mathrm{CT}$ and multidetector CT: a tale of two CTs. Dentomaxillofac Radiol 2012; 41: 637-644.

56. Horner K, Jacobs R, Schulze R. Dental CBCT equipment and performance issues. Radiat Prot Dosimetry 2013; 153: 212-218.

57. Pauwels R, Beinsberger J, Collaert B et al; The SEDENTEXCT Project Consortium. Effective dose range for dental cone beam computed tomography scanners. Eur J Radiol 2012; 81: 267-271.

58. SEDENTEXCT P. Radiation Protection No 172 Cone Beam CT for Dental and Maxillofacial Radiology, 2012

59. de Vos W, Casselman J, Swennen G R J. Cone-beam computerized tomography (CBCT) imaging of the oral and maxillofacial region: a systematic review of the literature. Int J Oral Maxillofac Surg 2009; 38: 609-625

60. Tsutsumi K, Chikui T, Okamura K, Yoshiura K. Accuracy of linear measurements and the measurement limits of thin objects with cone beam computed tomography: effects of measurement directions and of phantom locations in the fields of view. Int J Oral Maxillofac Implants 2011; 26: 91-100.

61. Marmulla R, Wortche R, Muhling J, Hassfeld S. Geometric accuracy of the NewTom 9000 Cone Beam CT. Dentomaxillofac Radiol 2005; 34: 28-31.

62. Maret $\mathrm{D}$, Telmon N, Peters 0 A et al. Effect of voxel size on the accuracy of $3 \mathrm{D}$ reconstructions with cone beam CT. Dentomaxillofac Radiol 2012 41: 649-655.

63. Mah P, Reeves T E, McDavid W D. Deriving Hounsfield units using grey levels in cone beam computed tomography. Dentmaxillofac Radiol 2010; 39: 323-335.

64. Bechara B B, Moore W S, McMahan C A, Noujeim $M$. Metal artefact reduction with cone beam CT: an in vitro study. Dentomaxillofac Radio/ 2012; 41: 248-253.

65. Spin-Neto R, Mudrak J, Matzen L H, Christensen A, Gotfredsen E, Wenzel A. Cone beam CT image artefacts related to head motion simulated by a robot skull: visual characteristics and impact on image quality. Dentomaxillofac Radiol 2013; 42: 32310645

66. Davies J, Johnson B, Drage N A. Effective doses from cone beam $C T$ investigations of the jaws. Dentomaxillofac Radiol 2012; 41: 30-36.

67. Roman S, Margrit-Ann G. Assessment of the effective doses from two dental CBCT devices. Dentomaxillofac Radiol 2013; 42: 20120273.

68. Hassan B A, Payam J, Juyanda B, van der Stelt $P$, Wesselink P R. Influence of scan setting selections on root canal visibility with cone beam CT. Dentomaxillofac Radiol 2012: 41: 645-648.

69. Ludlow J B. A manufacturer's role in reducing the dose of cone beam computed tomography examinations: effect of beam filtration. Dentomaxillofac Radio/ 2011: 40: 115-122.

70. Goren A D, Prins R D, Dauer L T et al. Effect of leaded glasses and thyroid shielding on CBCT radiation dose in an adult female phantom. Dentomaxillofac Radiol 2013; 42: 20120260.

71. Zanette I, Bech M, Rack A et al. Trimodal low-dose X-ray tomography. Proc Natl Acad Sci U S A 2012; 109: 10199-10204.

72. Sato A, Nakamoto N, Abe T et al. Preliminary results of a study comparing conventional radiography with phase-contrast radiography for assessing root morphology of mandibular third molars. Dentomaxillofac Radio/ 2011; 40: 91-95.

73. Bech $M$, Jensen T H, Bunk $O$ et al. Advanced contrast modalities for $\mathrm{X}$-ray radiology: phasecontrast and dark-field imaging using a grating interferometer. Z Med Phys 2010; 20: 7-16.

74. David C, Nohammer B, Solak H H, Ziegler E. Differential $X$-ray phase contrast imaging using a shearing interferometer. Appl Phys Lett 2002; 81: 287-289.

75. Jensen T H, Bech M, Bunk $O$ et al. Directional $x$-ray dark-field imaging. Phys Med Biol 2010; 55: 3317-3323.

76. Rutherford R A, Pullan B R, Isherwood I. Measurement of effective atomic number and electron density using an EMI scanner. Neuroradiology 1976: 11: 15-21.

77. Fredenberg E. Spectral mammography with X-ray optics and a photon-counting detector. Thesis. Stockholm, 2009.

78. Norlin B, Fröjdh C. Energy dependence in dental imaging with Medipix2. Nuclear instruments and methods in physics research Section A. Accelerators, Spectrometers, Detectors Associated Equipment 2005; 546: 19-23.

79. Watt J, Davidson D, Johnston C et al. Dose reductions in dental $\mathrm{X}$-ray imaging using Medipix. Nuclear Instruments and Methods in Physics Research A 2003; 513: 65-69.

80. Hurrell M A, Butler A P H, Cook N J, Butler P H, Ronaldson J P, Zainon R. Spectral Hounsfield units: a new radiological concept. Europ Radio/ 2012; 22: 1008-1013.

81. Lehmann L, Alvarez R, Macovski A et al. Generalized image combinations in dual KVP digital radiography. Med Phys 1981; 8: 659-667.

82. Alvarez R, Macovski A. Energy-selective reconstructions in X-ray computerized tomography. Phys Med Biol 1976; 21: 733-744.

83. Åslund M, Fredenberg E, Cederström B, Danielsson M. Spectral shaping for photon counting digital mammography. Nuclear Instruments and Methods in Physics Research Section A: Accelerators, Spectrometers, Detectors and Associated Equipment 2007: 580: 1046-1049.

84. White S C, Pharoah M J. The evolution and application of dental maxillofacial imaging modalities. Dent Clin North Am 2008; 52: 689705.

85. Dowsett D J, Kenny P A, Johnston R E. The physics of diagnostic imaging. 2nd ed. UK: Hodder Arnold, 2006.

86. Wolf G, Nicoletti R, Schultes G, Schwarz T, Schaffler $\mathrm{G}$, Aigner R M. Preoperative image fusion of fluoro2deoxyDglucose-positron emission tomography and computed tomography data sets in oral maxillofacial carcinoma: potential clinical value. $J$ Comput Assist Tomogr 2003; 27: 889-895.

87. Loeffelbein D J, Souvatzoglou M, Wankerl V et al. PET-MRI fusion in headandneck oncology: current status and implications for hybrid PET/MRI. J Oral Maxillofac Surg 2012; 70: 473-483.

88. Brix G, Lechel U, Glatting $G$ et al. Radiation exposure of patients undergoing whole-body dualmodality 18F-FDG PET/CT examinations. J NuCl Med 2005; 46: 608613

89. Goerres G W Schmid D T, Eyrich G K . Do hardware artefacts influence the performance of head and neck PET scans in patients with oral cavity squamous cell cancer? Dentomaxillofac Radiol 2003; 32: 365-371.

90. Jervis S E, Brettle D S. A practical approach to soft-copy display consistency for PCbased review workstations. Br J Radio/ 2003; 76: 648-652.

91. Krupinski E A, Berbaum K S. The Medical Image Perception Society update on key issues for image perception research. Radiology 2009; 253: 230-233. 